\title{
SURVIVAL OF BLASTOCYSTS IN THE UTERI OF OVARIECTOMIZED MICE
}

\author{
H. M. WEITLAUF AND G. S. GREENWALD \\ Departments of Obstetrics and Gynecology and Anatomy, \\ University of Kansas Medical Center, \\ Kansas City, Kansas, U.S.A.
}

(Received 18th January 1968, revised 7th May 1968)

\begin{abstract}
Summary. Mature mice were ovariectomized on the 4th day post coitum (Day 1 = vaginal plug) and given no further treatment. Unimplanted (delayed) blastocysts were recovered from these females between 5 and 40 days post coitum. They were tested for viability by determining the proportion that developed into normal foetuses following transfer to Day-4 pseudopregnant recipients.

It was found that the proportion of transferred blastocysts developing into foetuses was similar after delays of from 0 to 10 days. After delays of more than 10 days, the proportion of blastocysts that were capable of developing into normal foetuses decreased; 30 to $32 \%$ developed following transfer on Days 5 to 15,18\% with transfer on Day 20, and $3 \%$ with transfer on Day 30 . The finding that blastocysts can be delayed in the absence of ovarian hormones and yet remain capable of developing into normal foetuses demonstrates that progesterone is not essential for blastocyst survival in mice.
\end{abstract}

\section{INTRODUCTION}

Implantation does not occur in rats or mice that are ovariectomized before noon of the 4th day post coitum and in the absence of exogenous ovarian hormones the blastocysts remain free in the uterine lumen. Although it is known that exogenous hormones are necessary to induce implantation and to support normal foetal development after ovariectomy (Cochrane \& Meyer, 1957; Smithberg \& Runner, 1956, 1960; Yoshinaga \& Adams, 1966; Humphrey, 1967), there is disagreement as to whether exogenous progesterone is necessary for the maintenance of viable blastocysts during the period of delay. Canivenc \& Laffargue (1957) reported that some implantations could be induced in rats ovariectomized on Day 4 which received no progesterone till Day 14, but Nutting \& Meyer (1963) concluded that rat blastocysts did not survive delay in the absence of progesterone.

Similarly, existing experiments with mice do not clearly demonstrate whether the blastocysts can remain viable during delay, in the absence of hormones. In intact immature mice, where the induced corpora lutea are 
reported to regress (Smithberg \& Runner, 1956, 1960), blastocysts were delayed up to Day 15 p.c. without losing their ability to develop into foetuses. On the other hand, blastocysts delayed from implanting in ovariectomized immature mice did not retain this ability, although some did become implanted (Smithberg \& Runner, 1960).

The present study was undertaken to determine whether or not mouse blastocysts, delayed from implanting by ovariectomy, can remain viable in the absence of exogenous progesterone.

\section{MATERIALS AND METHODS}

The egg transfer technique was used with donors and recipients prepared as follows:

\section{Donors}

Blastocysts were obtained from 339 sexually mature, virgin, white Swiss mice. At any stage of their oestrous cycles these mice were induced to ovulate and mate by an intraperitoneal injection of 3 i.u. pregnant mare's serum gonadotrophin (PMSG) followed $48 \mathrm{hr}$ later by an injection of 5 i.u. human chorionic gonadotrophin (HCG) (Fowler \& Edwards, 1957). Immediately after the HGG injection each female was placed with a fertile male. The presence of a vaginal plug on the following morning (Day 1 of pregnancy) confirmed mating.

Bilateral ovariectomies were performed between 09.00 and 11.00 hours on Day 4 of pregnancy. To assure completeness of ovariectomy and to avoid damage to the oviduct the procedure was carried out with the aid of a dissecting microscope $(7 x)$. The ovariectomized mice with no further treatment were allotted to one of seven groups and killed at various times p.c. (Table 1).

\section{Recipients}

Recipients were induced to ovulate by the hormonal regimen already described; they were, however, mated to vasectomized males. Blastocyst transfers were done between 09.00 and 11.00 hours on Day 4 of pseudopregnancy.

\section{Blastocyst recovery and transfer}

Blastocysts were recovered by flushing the excised uterine horns with transfer medium $(0.9 \% \mathrm{NaCl}$ and homologous serum; $2: 1)$. The blastocysts from a single mouse were collected in a depression slide and five eggs were drawn into a micropipette for each transfer. Occasionally, less than five blastocysts were recovered (especially after delays of more than 15 days, see Table 1) and transfers were done with eggs pooled from two or more mice. In a few instances transfers were made with fewer than five blastocysts. The blastocysts were maintained in vitro less than 20 min before transfer.

The recipients were killed on Day 18 p.c. and the contents of the uteri were examined. Conceptuses were classified as normal or abnormal. The criteria for normal foetuses were: (1) grossly normal body form and weight; and (2) 
struggling movements by the foetus after removal of the amnion. Conceptuses classified as abnormal were either: (1) grossly deformed, small or dead embryos; or (2) implantation sites (defined as conceptuses represented only by swellings in the uterus remaining after implantation and foetal death). These criteria were established after examination of 157 Day-18 foetuses from normal pregnancies. The average weight of foetuses from normal pregnancies at Day 18 was $0 \cdot 89 \pm 0 \cdot 132 \mathrm{~g}$; foetuses weighing less than two standard deviations under this mean were considered abnormal.

In this paper the length of blastocyst delay is counted from Day 5 p.c. when implantation normally occurs; thus, blastocysts recovered on Day 9 were delayed 4 days.

\section{RESULTS}

Blastocysts which survived the delay period and hormonal deprivation were recovered and counted (Table 1). Of the females killed on Day 5 (Group 1,

TABLE 1

SURVIVAL OF BLASTOCYSTS IN THE UTERI OF OVARIEGTOMIZED MICE

\begin{tabular}{|c|c|c|c|c|c|}
\hline Group & $\begin{array}{r}(1) \\
\text { Recover } \\
\text { blastoc } \\
\text { Days post } \\
\text { coitum }\end{array}$ & $\begin{array}{l}\text { of } \\
\text { ysts } \\
\text { Days of } \\
\text { delay }\end{array}$ & $\begin{array}{c}(2) \\
\text { Total no. } \\
\text { of mice }\end{array}$ & $\begin{array}{c}\text { (3) } \\
\text { No. of mice } \\
\text { with one or more } \\
\text { blastocysts in } \\
\text { utero } \% \text { of total) }\end{array}$ & $\begin{array}{c}(4) \\
\text { Average no. of } \\
\text { blastocysts per mouse } \\
\text { with one or more } \\
\text { blastocysts in utero } \\
\text { No. ( } \pm \text { S.E. })\end{array}$ \\
\hline $\begin{array}{l}1 \\
2 \\
3 \\
4 \\
5 \\
6 \\
7\end{array}$ & $\begin{array}{r}5 \\
9 \\
15 \\
20 \\
30 \\
35 \\
40\end{array}$ & $\begin{array}{r}0 \\
4 \\
10 \\
15 \\
25 \\
30 \\
35\end{array}$ & $\begin{array}{l}33 \\
45 \\
53 \\
54 \\
79 \\
13 \\
19\end{array}$ & $\begin{array}{c}29(88) \\
34(75) \\
29(55) \\
36(66) \\
37(47) \\
7(54) \\
1 *\end{array}$ & $\begin{array}{l}7.9 \pm 0.65 \\
7.6 \pm 0.65 \\
6 \cdot 1 \pm 0.34 \\
5 \cdot 3 \pm 0.46 \\
2.9 \pm 0.28 \\
2.4 \pm 0.72 \\
\end{array}$ \\
\hline
\end{tabular}

* One blastocyst recovered from one of nineteen mice.

no delay), $88 \%$ had one or more blastocysts in the uterus. In contrast, blastocysts were recovered from only about half $(47$ to $66 \%$ ) of the mice killed after delays of 10 or more days (Table 1; Groups 3 to 6). In addition to the loss of all blastocysts from some mice it was found that in others with retained blastocysts, fewer eggs were recovered as the length of delay increased. This reduction was progressive throughout the period of delay (Table 1, column 4). There were three possible explanations for the loss of blastocysts: (1) they may have been flushed out of the uterus through the cervix; (2) they may have died in the uterus and undergone cytolysis; or (3) a combination of these two mechanisms may have been responsible for the loss of all blastocysts from some mice, and for the loss of individual blastocysts from others.

In an attempt to distinguish between these possibilities, the uteri of several mice were ligated near the cervical ends on Day 9 p.c. These females were killed on Day 10 or 30 and their uteri flushed to recover retained blastocysts (Table 2). The proportion with retained blastocysts and the average number of blastocysts per mouse were not significantly different on Day 10 or 30 . 
However, many of the blastocysts $(46 \%)$ were degenerating in the ligated uteri of mice killed on Day 30. It appeared, therefore, that the progressive loss of blastocysts from unligated uteri during the period of delay was occurring both through the cervix and by cytolysis.

The blastocysts were tested for viability after delay and hormone deprivation by transferring them to pseudopregnant recipients (Table 3). Of the undelayed blastocysts transferred on Day 5 (Group 1) 32\% developed into normal foetuses. Delays of 4 days (Group 2) and of 10 days (Group 3 ) did not affect the proportion of blastocysts which developed into foetuses (Table 3). Blastocysts therefore can survive delay and hormone deprivation up to 10 days

TABLE 2

RETENTION OF BLASTOCYSTS IN THE LIGATED UTERI* OF MICE OVARIEGTOMIZED ON DAY post coitum

\begin{tabular}{c|c|c|c}
\hline $\begin{array}{c}\text { No. of } \\
\text { females }\end{array}$ & $\begin{array}{c}\text { Killed } \\
\text { on Day: }\end{array}$ & $\begin{array}{c}\text { No. of mice } \\
\text { with one or more } \\
\text { blastocysts in } \\
\text { utero (\% of total) }\end{array}$ & $\begin{array}{c}\text { Average no. of } \\
\text { blastocysts per mouse } \\
\text { with one or more } \\
\text { blastocysts in utero } \\
( \pm S . E .)\end{array}$ \\
\hline 16 & 10 & $13(81 \%)$ & $6.5 \pm 1.8$ \\
21 & 30 & $15(71 \%)$ & $4.06 \pm 0.89$ \\
\hline
\end{tabular}

* Uteri ligated on Day 9 post coitum.

TABLE 3

FOETAL DEVELOPMENT FOLLOWING TRANSFER OF BLASTOCYSTS RECOVERED FROM UTERI OF OVARIEGTOMIZED MICE

\begin{tabular}{c|c|c|c|c|c|c}
\hline Group & $\begin{array}{c}\text { Length of } \\
\text { delay } \\
\text { (days) }\end{array}$ & $\begin{array}{c}\text { No. of } \\
\text { recipients }\end{array}$ & $\begin{array}{c}\text { No. of } \\
\text { recipients } \\
\text { pregnant on } \\
\text { Day 18 }\end{array}$ & $\begin{array}{c}\text { No. of } \\
\text { blastocysts } \\
\text { transferred }\end{array}$ & $\begin{array}{c}\text { No. of normal } \\
\text { foetuses on Day 18 } \\
\text { (\% of transferred } \\
\text { blastocysts) }\end{array}$ & $\begin{array}{c}\text { No. of } \\
\text { abnormal foetuses } \\
\text { (\%of transferred } \\
\text { blastocysts) }\end{array}$ \\
\hline 1 & 0 & 25 & 14 & 123 & $40(32 \cdot 5)$ & $7(5 \cdot 7)$ \\
2 & 4 & 27 & 15 & 135 & $42(31 \cdot 3)$ & $18(13 \cdot 3)$ \\
3 & 10 & 12 & 7 & 57 & $17(30 \cdot 0)$ & $10(17 \cdot 5)$ \\
4 & 15 & 26 & 12 & 127 & $23(18 \cdot 1)$ & $20(15 \cdot 7)$ \\
5 & 25 & 19 & 3 & 59 & $2(3 \cdot 4)$ & $5(8 \cdot 5)$ \\
\hline
\end{tabular}

without appreciable harm. On the other hand, with delays of more than 10 days the proportion of blastocysts capable of complete development was sharply reduced. After a delay of 15 days (Group 4 ) only $18 \%$ of the transferred blastocysts became foetuses, and with a delay of 25 days (Group 5) only about $3 \%$ (Table 3 ).

The number of abnormal conceptuses in each group is summarized in Table 3; most of these were simply implantation sites containing remnants of foetal placenta. However, dead or very small embryos were also found; one in Group 1, one in Group 2, two in Group 3, and one in Group 4.

Because of the low percentage of blastocysts which developed after a delay of 25 days (Group 5) and the small number of blastocysts recovered from these 
donors, transfers were not done in the remaining groups (Groups 6 and 7, Table 1).

\section{DISCUSSION}

The present experiments demonstrate that a small percentage of mouse blastocysts, prevented from implanting by ovariectomy, may remain viable during 25 days' delay, despite the absence of ovarian hormones. It follows that mouse blastocysts have no obligatory requirement for progesterone during delayed implantation.

In some of the earlier experiments, the viability of blastocysts surviving delay in ovariectomized females was tested only by the formation of implantation sites, and complete foetal development was not reported. The experiments of Smithberg \& Runner (1960) with prepuberal mice showed that mouse blastocysts could implant after prolonged delays and hormone deprivation (up to 31 days), but the blastocysts did not develop into normal foetuses. Probably they had deteriorated during the long delay.

Unless egg transfers are carried out with the delayed blastocysts it is impossible to distinguish between two different causes of embryonic failure, damage to the blastocyst or inadequate hormonal preparation of the uterus of the recipient (Noyes \& Dickmann, 1960).

Implantation and complete foetal development were used here as proof of blastocyst viability. The possibility of 'false negative' results (i.e. because of failure to synchronize the uterus and the blastocysts) was ruled out by transferring all blastocysts to uteri that were known to be capable of supporting implantation and normal foetal development. The decrease in the proportion of transferred blastocysts which developed into foetuses after more than 10 days' delay indicates limits to blastocyst viability similar to those found when implantation in mice is delayed from other causes, e.g. the delay in post partum pregnancy with concurrent lactation which is generally less than 10 or 11 days (i.e. implantation by Day 15 or 16 p.c.) (Mantalenakis \& Ketchel, 1966). In intact prepuberal mice normal embryonic development occurs only if blastocysts are delayed 10 days or less (Smithberg \& Runner, 1960). One possible explanation for the loss of viability following delay of more than 10 days under these various conditions is that the blastocysts may be depleted of reserves of stored nutrients.

The present experiments provide proof that blastocysts of mature mice, delayed from implanting by ovariectomy, remain viable for delays of at least 10 days in the absence of supplemental hormones. This form of experimental delayed implantation therefore offers a convenient model to analyse the hormonal control of implantation in the mouse.

\section{AGKNOWLEDGMENT}

This work was supported by a grant (HD 00596-06) from The National Institutes of Health, United States Public Health Service, and from The Ford Foundation. H. M. Weitlauf was supported by a United States Public Health Service post-doctoral fellow. 


\section{REFERENCES}

Ganivenc, M. \& Laffargue, M. (1957) Survie des blastocystes de rat en l'absence d'hormones ovariennes. C.r. hebd. Séanc. Acad. Sci., Paris, 245, 1752.

Cochrane, R. L. \& Meyer, R. K. (1957) Delayed nidation in the rat induced by progesterone. Proc. Soc. exp. Biol. Med. 96, 155.

Fowler, R. E. \& EDWARDs, R. G. (1957) Induction of superovulation and pregnancy in mature mice by gonadotrophins. F. Endocr. 15, 374.

Humphrey, K. (1967) The development of viable embryos after ovum transfers to long term ovariectomized mice. Steroids, 9, 53.

Mantalenakis, S. J. \& Ketchel, M. K. (1966) Frequency and extent of delayed implantation in lactating rats and mice. 7. Reprod. Fert. 12, 391.

Noyes, R. W. \& Dickmann, Z. (1960) Relationship of ovular age to endometrial development. $\mathcal{F}$. Reprod. Fert. 1, 186.

Nutring, E. H. \& MEyer, R. K. (1963) Implantation delay, nidation and embryonal survival in rats treated with ovarian hormones. In: Delayed Implantation. Ed. A. Enders. University of Chicago Press.

Smithberg, M. \& Runner, M. N. (1956) The induction and maintenance of pregnancy in prepuberal mice. 7. exp. Zool. 133, 441 .

Smtthberg, M. \& Runner, M. N. (1960) Retention of blastocysts in non-progestational uteri of mice. 7. exp. Zool. 143, 21.

Yoshinaga, K. \& Adams, C. E. (1966) Delayed implantation in the spayed, progesterone treated adult mouse. 7. Reprod. Fert. 12, 593. 